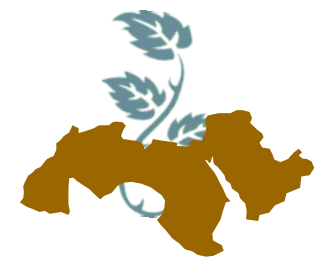

Arab Univ.

\title{
REUSE OF WASTE DRAINAGE WATER AFTER ITS TREATMENT USING PGPRS TO IRRIGATE SOME HORTICULTURAL CROPS
}

Marwa I. KahliI ${ }^{1}$; Wedad E. Eweda ${ }^{2}$; M.N. Omar ${ }^{1}$; Mona M. Orabi ${ }^{2}$ and K.A. Imam ${ }^{3}$

1- Soils, Water and Environment Res., Ins., ARC, Giza, Egypt

2- Agric. Microbiological Dept., Fac. of Agric., Ain Shams Univ., Cairo, Egypt

3- Horticultural, Res., Ins., ARC, Giza, Egypt

Keywords: Bioremediations; Phytoremediation; Heavy metals; Pathogenic bacteria; PGPRs; Mentha viridis $\mathrm{cv}$, Gladiolas grandiflorus $\mathrm{cv}$.

\section{ABSTRACT}

Natural sources of water are limited in Egypt. The rapidly growing populations necessitate continuous expansion of the cultivated area. This means an increase of the gap between the demands of water for irrigation and the limited water supply. Looking for other sources such as low quality water like (industrial effluent, drainage and sewage) must be used in irrigation of some garden and wood plants. This investigation was conducted on agricultural drainage wastewater from El Mohete drain (Marioteya Canal) west of Cairo; the samples were collected from different places during (Summer and Winter seasons). The wastewater contaminated with pathogenic microorganisms, the excess of fertilizers (inorganic \& organic), heavy metals, and the residuals of pesticides. Plant Growth Promoting Rhizobacteria (PGPR) could remediate the wastewater as biological bioremediation to remove some pollutants such as pathogenic microorganisms, heavy metals and pesticides. Chemical remediation was used as nitrification inhibitor to stop transformation of ammonia to nitrate. This work was conducted to study the ability of PGPR strains e.g. Bacillus megaterium, Bacillus subtillis, Bacillus circulans, Paenibacillus polymyxa, Pseudomonas floresense, Serratia sp. and Azotobacter chroococcum 5, 9 and 23 to treat the drainage water for irrigation the Mentha viridis cv. and Gladiolas grandiflorus cv. plants.

Two pot experiments were conducted in greenhouse. The treatments were applied as follows; Natural water, treated water and drainage water to irrigate the plant. Use the PGPR as inoculants and thiourea as nitrification inhibitor, Heavy metal treated was (Copper, Cobalt, Zinc, Cadmium and Mercury) the result showed us heavy metals removal by PGPR from drainage water.

The characterizations of PGPRs as shown in the obtained results are they could enhance plant growth by using their own metabolism (solublizing phosphate, producing hormones or fixing nitrogen) as well as correlation of them with the potenit of effects on the growth of plants in unfavorable conditions in order to improve the efficiency of phytoremdiation of contarinated soils. The removal of heavy metals and the elimination of pesticides residues were markedly noticed in this investigation. Results also confirmed the ability of PGPRs in suppressing the effect of pathogenic bacteria like Salmonellasp and E.coli. These abilities are of great importance in terms of plant and soil health. Consequently, the role of PGPRs bacteria associated with plant rhizosphere in remediation of water and soil contaminations due to its biochemical activity and thus, stimulate plant growth is a great important subject in phytoremediation process nowadays.

\section{INTRODUCTION}

Water pollution is stated as "a change in the chemical, physical, biological, and radiological quality of water that is injurious to its existing, intended, or potential uses" (Water Pollution, 2002). The implications of pollution on the Earth began many years ago with the inconsiderate behaviors and careless attitude toward the environment.

A major concern for reuse of agricultural waste drainage water is the bioaccumulation of hazardous wastes especially heavy metals and pesticides 
in food chain. Also heavy metals affect the enzyme activity within the plant with subsequent reduction in yield (Teisseire and Guy, 2000). In aquatic systems, heavy metals can be found in different forms (Cheung et al 2003). The problem of heavy metal pollution is basically associated with: (i) acute toxicity linked with particular metals $(\mathrm{Cu}, \mathrm{Hg}$ or $\mathrm{Cd}$ ), even in lower concentration; (ii) the fact that heavy metals are not degraded or destroyed and tend to circulate; thus, they remain for a long time in nature and are accumulated through the food chain, which leads to serious ecological and health problems (Eman R. Zaki 2014).

Agricultural wastewater contains pathogenic microorganisms such as bacteria, viruses, and parasites, which have the potential to cause diseases. In particular, human parasites such as protozoa and helminthes eggs are of special significance in this regard as they prove to be most difficult to remove by treatment processes and have been implicated in a number of infectious gastrointestinal diseases in both developed and developing countries. The use of untreated agricultural wastewater for irrigation, no doubt, poses a high risk to human health in all age groups. However, the degree of risk may vary among the various age groups (Feenstra et al 2000). Treatment of pollutants in agricultural wastewater is the process of removing contaminations from wastewater and effluents. It includes physical, chemical, and biological processes to remove the contaminants. Its objective is to produce an environmentally-safe fluid treated effluent and solid waste suitable for reuse usually as farm fertilizer (Emane R. Zaki 2014).

Bioremediation is a "treatment that uses naturally occurring organisms to break down hazardous substances in to less toxic or non-toxic substances". Microbial degradation of pesticides has been recognized as the most important process (Karpouzas and Singh, 2006). therefore, biodegradation using native microorganisms for pesticides removal from the environment is quite attractive (Maya et al 2011).

Heavy metal resistant bacteria have significant role in bioremediation of heavy metals in wastewater. The heavy metals $\mathrm{Hg}$ and $\mathrm{Cu}$ were removed by Bacillus sp. The average $\mathrm{Hg}$ reduction was $45 \%$ and $\mathrm{Cu}$ reduction was recorded as $62 \%$. The heavy metals $\mathrm{Cd}$, As and Co were removed by Pseudomonas $\mathrm{sp}$. The average $\mathrm{Cd}$ reduction was $56 \%$, average As reduction was $34 \%$ and average Co reduction was recorded as $53 \%$. (Manisha et al 2011).
The PGPRs can indirectly or directly affect plant growth. Indirect plant growth promotion includes the prevention of the deleterious effects of phytopathogenic organisms. This can be achieved by the production of siderophores, i.e. small ironbinding molecules. In soils, iron is found predominately as ferric ions, a form that cannot be directly assimilated by microorganisms (Heba M. Hewait, 2010). Another mechanism by which PGPR can inhibit phytopathogens is the production of hydrogen cyanide $(\mathrm{HC})$ and/or fungal cell wall degrading enzymes e.gchitinase and $\beta-1, \quad 3$-glucanase (Friedlender et al 1993).

Symbiotic and non-symbiotic PGPRs may also promote plant growth directly through production of plant hormones such as auxins (Tien et al 1979), gibberellins (Gutiérrez-Mañero et al 2001) and ethylene (Lynch, 1990 and Heba M. Hewait 2010).

The objective of this study is to use some PGPRs in removing some organic, inorganic and biological pollutants in a agricultural waste water to be used in irrigation of some horticultural crops (Mint and Gladiolas).

\section{MATERIALS AND METHODS}

Bioremediation of agricultural wastewater become an urgent necessity nowadays to face the challenges in water resources shortage. Using microbial strains have the ability to eliminate the pollutants in agricultural wastewater is considered a promising way as it is safe and cheap. The ability of some bacterial species to degrade the toxic effect of pollutants in agricultural wastewater and at the same time its use as plant growth promoters is our main target in this study.

\section{Agricultural wastewater collection}

Ten samples were collected from different localities along Marioteya (El-Mohate drainage canal).

The samples were collected in sterilized highdensity polyethylene bottles and immediately brought to the laboratory in an ice box and stored at $4{ }^{\circ} \mathrm{C}$ to carryout physical, chemical and biological analysis $100 \mathrm{ml}$ from each bottle were taken and mixed thoroughly to reach 1 liter of homogenized sample which represents the 10 sites and be used for analysis. 


\section{Bacterial strains}

Some plants growth promoting rhizobacteria via; Bacillus megaterium , Bacillus subtilis , BacilIus circulans, Paenibacillus polymyxa, Pseudomonas flouresens and Serratia sp. were kindly obtained from the department of agricultural microbiology, Soils, water and environment Research Institute (SWERI), Agricultural Research center (ARC) Giza, Egypt whereas three Azotobacter strains; Azotobacter chroococcum (Azo.3), (Azo.9) and $(A z o .23)$ were obtained from the department of microbiology, Faculty of agriculture, Ain shams university, Cairo, Egypt.

These bacterial strains were grown and maintained on their specific media for each as follows;

Bacillus megaterium strain was cultivated in pikoveskay's medium (Pikoveskaya, 1948) for 3 days at $30^{\circ} \mathrm{C}$ to reach $1 \times 10^{8} \mathrm{clle} / \mathrm{ml}$ culture.

Bacillus subtilis was cultivated in nutrient broth medium (Difco, 1985) and incubated for $48 \mathrm{~h}$ at $28^{ \pm}$ ${ }^{2} \mathrm{C}$ to reach $1 \times 10^{8}$ cell $/ \mathrm{ml}$ culture.

Bacillus circulans strain was grown and maintained on Alexandrov's broth medium (Zahara, 1969) and incubated for 4 weeks at $28^{\circ} \mathrm{C}$ to reach maximum growth $1 \times 10^{8}$ cell/ ml culture.

Three nitrogen fixers strains belong to genius Azotobacter via, AZtobacter chroococcum (Azo.3), Azo.9 and Azo.23 were grown on modified Ashby's medium (Abdel-Malek and Ishac, 1968) at $30^{\circ} \mathrm{C}$ for 7 days to reach the finial desity of $10^{8} \mathrm{cfu} / \mathrm{ml}$ culture according to (Cochran, 1950).

An active strain of Pseudomonas fluorescens was cultured and maintained on King's broth medium (King et al 1954) at $28 \pm 2^{\circ} \mathrm{C}$ for 7 days. The biomass of $P$. fluoresens was prepared by inoculating $1 \mathrm{ml}$ of pre-culture of Pseudomonas fluoresens $\left(1 \times 10^{8} \mathrm{cfu} \mathrm{\textrm {ml } ^ { - 1 } )}\right.$ in a $500 \mathrm{ml}$ Erlenmeyer flask containing $200 \mathrm{ml}$ of King's broth medium, then incubated on a rotatory shaker $(120 \mathrm{rpm})$ for 72 hour at $28 \pm 2^{\circ} \mathrm{C}$. The density of bacterial cell culture was adjusted to $10^{8} \mathrm{cell} / \mathrm{ml}$. peanibacillus polymyxa strain was grown and maintained on nutrient broth medium (Difco, 1985). This strain was cultured on this medium for $48 \mathrm{~h}$ at $28 \pm 2^{\circ} \mathrm{C}$ to reach $10^{8} \mathrm{cell} / \mathrm{ml}$ culture.

Serratia spp: An active strain was obtained from the department of agricultural microbiology, soils, waters and environment research Institute (SWERI), agriculture research center (ARC), Giza, Egypt.

This strain was cultured in $100 \mathrm{ml}$ nutrient broth medium (Difco, 1985) in a 250 conical flasks. The flasks were incubated for $48 \mathrm{~h}$ at $28 \pm 2^{\circ} \mathrm{C}$ to reach the density $1 \times 10^{8} \mathrm{cell} / \mathrm{ml}$.
Antagonistic action of the used strains against pathogenic microbial pollutants

\section{In vitro Inhibition test}

The antimicrobial activity of the used PGPR's (cell free filtrate) against (Escherichia coli and Salmonella spp.,), that isolated from agricultural wastewater samples by the well diffusion assay. The pathogenic bacteria were incubated in Brain heart Infusion (BHI) broth at appropriate temperature for $24 \mathrm{hrs}$. Petri dishes containing $20 \mathrm{ml}$ of Muller Hinton agar were prepared previously and inoculated with $0.1 \mathrm{ml}$ of $24 \mathrm{hrs}$ broth culture of pathogenic bacteria. Once solidified the dishes were stored for 2 hrs in a refrigerator. Four wells were made and filled using $100 \mu \mathrm{l}$ of cell-free filtrate of each PGPRs according to (Lee, S.W., et al 2010). Incubation of the Petri dishes at $37^{\circ} \mathrm{C}$ for 42 hrs then the diameter of the inhibition zone was measured with calipers in $\mathrm{mm}$. The antimicrobial activity was determined by measuring the clear zone around the wells (Lee, S.W., et al 2010) and (Lee and Wendy (2013).

The antagonistic activity against $E$. coli and Salmonella sp. was carried out by using the PGPR's individually, in dual and in groups.

\section{Agricultural wastewater analysis}

\section{Microbiological examinations}

The examination of wastewater samples microbiologically was conducted to determine the populations of some pathogenic microorganisms Total Coliform, Fecal Coliform, Salmonella and Shigella (SS) were counted according to (Apha, 1989).

Chemical analysis of untreated and treated drainage wastewater included; $\mathrm{PH}, \mathrm{EC}, \mathrm{COD}$, BOD, Total phosphorus, Total nitrogen, Total potassium, Heavy metals, Hydrocarbons, $\mathrm{NH}^{+}$, $\mathrm{NO}^{-}$ and $\mathrm{NO}^{-} \mathrm{N}$ analysis were determined according to (Apha, 1989).

\section{Pot experiments}

Two pot experiments were conducted to study the effect of the treated agricultural wastewater biologically by using the different strains of PGPRs (Bacillus megaterium, Bacillus subtillus, Bacillus circulans, Paenibacillus polymyxa, Pseudomonas flouresens and Serratia sp. and three Azotobacter strains; Azotobacter chroococcum (Azo.3), (Azo.9) and (Azo.23). and chemically through nitrification inhibitors via, thiourea when used to irrigate Gladiolas as Horticultural crops and Mint as an ornamental plant. 
Table 1. Chemical analysis of Homogenized agricultural wastewater

\begin{tabular}{|c|c|c|c|c|c|c|c|c|c|c|c|c|c|}
\hline Sample & EC & PH & COD & BOD & TS & TSS & Fe & $\mathrm{Cu}$ & Zn & Mn & K & NA & P \\
\hline Homogenized & 3.1 & $\begin{array}{c}7.8 \\
(\mathrm{dSm}- \\
(\mathrm{dSm}- \\
1)\end{array}$ & $\begin{array}{c}6.9 \\
\mathrm{mg} / \mathrm{L}\end{array}$ & $\begin{array}{c}9.8 \\
\mathrm{mg} / \mathrm{L}\end{array}$ & $\begin{array}{c}2.59 \\
\mathrm{~g} /\end{array}$ & $\begin{array}{c}1.75 \\
\mathrm{~g} /\end{array}$ & $\begin{array}{c}0.03 \\
\mathrm{Ppm}\end{array}$ & $\begin{array}{c}0.29 \\
\mathrm{ppm}\end{array}$ & $\begin{array}{c}0.12 \\
\mathrm{ppm}\end{array}$ & 0.0 & $\begin{array}{c}17.8 \\
\mathrm{ppm}\end{array}$ & $\begin{array}{c}0.04 \\
\mathrm{ppm}\end{array}$ & $\begin{array}{c}5.7 \\
\mathrm{Ppm}\end{array}$ \\
\hline
\end{tabular}

Table 2. Different counters standers of heavy metals (El-Tohamy, S.A. et al 2015)

\begin{tabular}{|c|c|c|c|c|c|c|c|}
\hline Elements & $\mathrm{Cd}$ & $\mathrm{Cr}$ & $\mathrm{Cu}$ & $\mathrm{Ni}$ & $\mathrm{Pb}$ & $\mathrm{Zn}$ & $\mathrm{Mn}$ \\
\hline $\mathrm{Eu}$ & $1-3$ & $100-150$ & $50-140$ & $30-75$ & $50-300$ & $150-300$ & - \\
\hline
\end{tabular}

Soil: Clay soil was used to fill plastic pots $(30 \mathrm{~cm}$ diameter) with $5 \mathrm{~kg}$ soil for Gladiolas experiment.
And (15 cm diameter) with $2.5 \mathrm{~kg}$ soil for mint experiment. The physic-chemical analysis of soil was illustrated in Table (3).

Table 3. Physic-chemical analysis of the used soil

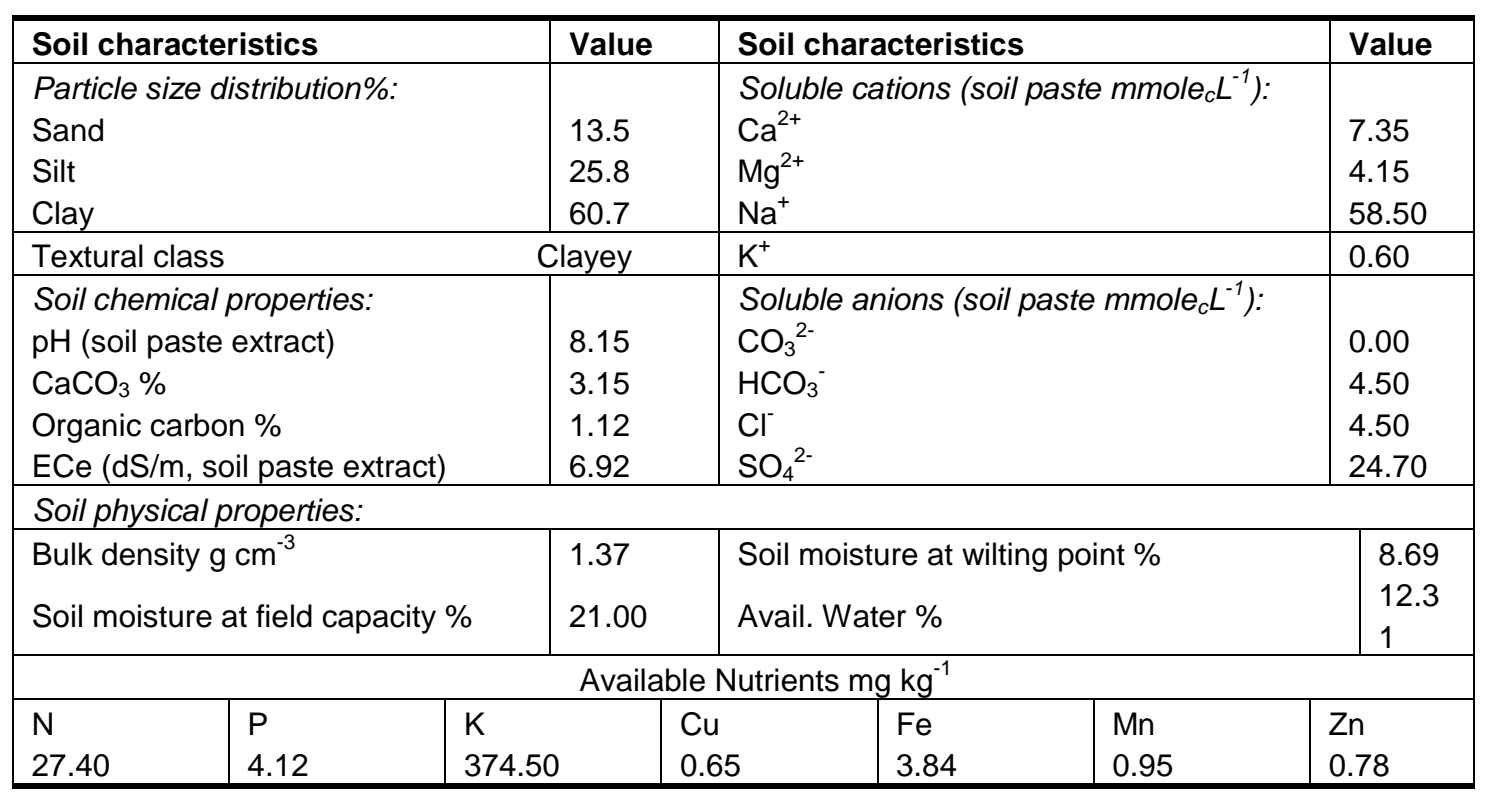

\section{Plant material}

Bulbs of Gladiolas and seedlings of Mint were kindly obtained from Horticulture Research Institute, ARC, Giza, Egypt. The two pot experiments were conducted in a greenhouse located at wheat research institute, ARC, Giza, Egypt. Each treatment has four replicates.
Irrigation: The two experiments were irrigated twice a week with the filtration of Homogenized treated agricultural wastewater.

Fertilization: The recommended dose of nitrogen fertilizer (nitrogen $120 \mathrm{Kg} / \mathrm{fed}$ ) as ammonium sulphate $(20.6 \% \mathrm{~N})$ was applied in three equal doses at $1^{\text {st }}, 2^{\text {nd }}$ and $3^{\text {rd }}$ irrigation, $200 \mathrm{Kg}$ super phosphate/fed (15.5\% P2O5) and $100 \mathrm{Kg} / \mathrm{fed}$ as potassium sulphate $\left(48 \% \mathrm{~K}_{2} \mathrm{O}\right)$ were used before cultivation (Omar et al, 2014). The experiments were planted on the $10^{\text {th }}$ of November, 2016. 
First experiment: Data recorded on Gladiolas grandiflorus cv.

After 110 days from planting when the flowers reached the second floret stage of blooming. Plant samples were collected, and the following data were recorded:

\section{1-Vegetative growth parameters}

Plant height $(\mathrm{cm})$ and Number of leaves/plant.

\section{2-Flowering parameters}

Length of cut spike $(\mathrm{cm})$, Spike stem diameter $(\mathrm{cm})$, Rachis length $(\mathrm{cm})$, Number of florets/spike, Diameter of the first floret $(\mathrm{cm})$, Fresh weight of cut spike (g) and Dry weight of cut spike (g).

\section{3- Chemical constituents}

\section{Pigments content in leaves}

Chlorophyll (a), Chlorophyll (b) and Carotenoids.

\section{Second experiment: Data recorded on Mentha viridis cv.}

After 70 days from planting plant samples were collected and the following data were recorded:

\section{1-Plant morphology}

Plant height $(\mathrm{cm})$ and Number of leaves/plant.

\section{2-Plant parameters}

Stem diameter $(\mathrm{cm})$, Fresh weight of plant $(\mathrm{g})$ and Dry weight of plant $(\mathrm{g})$.

\section{3-Root growth parameters}

Root length (cm)

\section{4-Chemical constituents}

\section{a-Pigments content in leaves} noids.

Chlorophyll (a), Chlorophyll (b) and Caroteb- Mineral $\%$ of Oil Mintol (ml/100g plant)

Determination of percentage and oil yield / plant:
Essential oil percentage in the fresh herb was determined according to (British Pharmacopoeia, 1963).

\section{Chemical analysis}

a- Leaf pigments (chlorophyll a, b and carotenoids)

The concentration $(\mathrm{mg} / \mathrm{g}$ fresh matter) of pigments (chlorophyll a, b and total carotenoids) were determined in leaf samples, according to Wettestein (1957) a five discs (one $\mathrm{cm}$ in diameter) of fresh tissues (flag leaf) were weighed, cut into small pieces and mixed in to a mortar with $80 \%$ $(\mathrm{v} / \mathrm{v})$ acetone in water.

Weighed $0.1 \mathrm{~g}$ of fresh plant with $10 \mathrm{ml}$ acetone, add $5 \mathrm{ml}$ acetone throw grinding. To prevent transformation of chlorophyll to pheophyten the homogenate was filtrated through a glass funnel of final porosity and residue was washed with $5 \mathrm{ml}$ of acetone, in order to isolate the pigments. The filtrate its optical density was spectrophotometerically (Spectronic 21 D Milton Roy Company) measured at wave lengths of $663.2,646.8$ and $470 \mathrm{~nm}$. The concentration of photosynthetic pigments was measured as follows:

Ch-a=12.25 $\times$ A663.2 $-279 \times$ A646.8 = mg/g $C h-b=21.5 \times A 646.8-5.1 \times A 663.2=\mathrm{mg} / \mathrm{g}$ Carotenoids $=((1000$ X A470 $)-(1.82 \mathrm{Ca}-$ 85.02Cb)) $/ 198=m g / g$

Where: Chl.a, $\mathrm{b}$ and carot. = concentrations of chlorophyll, a, b and carotenoids in $\mathrm{mg} / \mathrm{g}$ fresh weight.

$A=$ optical density at the wave length indicated.

\section{Dehaydroginas activity in the used soil}

The dehydrogenase activities ( DHA ) in rhizosphere soil, non rhizosphere soil either waterlogged or normally irrigated as well as in washed rise roots were estimated as indication of the respiratory activity of soil micro-organisms in each system using 2, 3, 5- Triphenyl tetrazolium chloride (TTC ) in tris- buffer according to the method described by (Thalmann, 1967).

Statistical analysis: Data collected from the two experiments were subjected to (One way analysis of variance) using the (MSTAT-C) program (SAS, 2006. Statistical Analysis System). Mean separation was performed using the New Multiple Range Test at the 5\% level of significance, as described by Duncan (1955) and Steel et al (1997). 


\section{RESULTS AND DISCUSSION}

Table 4. Heavy metals (mg/L) concentration in *Homogenized sample of agricultural wastewater using growing PGPR for $48 \mathrm{hr}$ at $30^{\circ} \mathrm{C}$.

\begin{tabular}{|l|c|c|c|c|}
\hline Microbes (PGPR) & Copper & Zinc & Nickel & Cobalt \\
\hline Control & 301.7 & 50 & 50 & 50 \\
Azotobacter chroococcum 9 & 242.4 & 40 & 48 & 47 \\
Serratia marcescens & 239.6 & 43 & 49 & Not Detected \\
Azotobacter chroococcum 23 & 50 & 45 & 45 & 44 \\
Pseudomonas Flourecens & 47 & 48 & 44 & 42 \\
Bacillus Circulans & 45 & 45 & 49 & 45 \\
Bacillus Megatherium & 44 & 46 & 45 & 43 \\
Bacillus Sabtilis & 48 & 44 & 42 & 41 \\
Paenibacillus Polymyxa & 40 & 40 & 46 & 45 \\
Azotobacter chroococcum 5 & 141.6 & 41 & 47 & 47 \\
Mix (Azo9, Sr, Bs, Bm,Pf) & Not Detected & 40 & 40 & Not Detected \\
\hline
\end{tabular}

${ }^{*}$ Homogenized sample is a mixture of 10 samples collected from ten sites along EL-Mohet canal.

*Mercury and Cadmium were not detected.

As shown in Table (4) the concentration of heavy metals in the untreated homogenized agricultural waste water sample varied from element to another.

The concentration of heavy metals as in control treatment (untreated) exceeded the critical limit with Copper $301.7 \mathrm{mg} / \mathrm{L}$ according to Urbian Standers whereas the concentrations of Zinc, Nickal and cobalt were the same and were below the critical range $50 \mathrm{mg} / \mathrm{L}$. There is No detection for both mercury and cadmium. The PGPRs could reduce the concentration of Copper compared to control where the average $\mathrm{Cu}$ reduction was 19.7 $\%$ by (Azo.3) and $20.6 \%$ by Serratia and $53.6 \%$ by (Azo.5) and ranged between 85.42 to 86.74 with other PGPRs.

For Mercury and Cadmium there is no detection in control and other treatments. The reduction of Zinc, Nickal and cobalt ranged between 2-20\% compared to control by all other Treatments. The mixture of PGPR's treatment is considered the best one as it agricultural waste water sample.

The PGPRs facilitated the removal of metals from water and this based on the ability of these microorganisms to complex and precipitate metals and the specific interactions for metal removal include metal binding to microbial cell surfaces and expolymer layers intracellular uptake, metal volatilization and metal precepitions via, microbially facil- itated metal redoxreactions (Scholz and $\mathrm{Xu}$, 2002)

Data in Table (5) show the ability of the used PGPRs to degrade and remove the pesticide residues from the polluted agricultural waste water that originally found in little amounts.

The organophosphours pesticides like, Atrazine, Propamocarb, Piperonyl butoxide, Chloropyrifors are found in untreated waste water sample in concentrations, $0.1,0.14$ and $0.05 \mathrm{mg} / \mathrm{kg}$ for Atrazine, Propamocarb and Chlorpyrifos respectively. All PGPRs could induce biodegration of pesticides and B.megaterium, B.subtilius, Serratia, Azotobacter 3 and Azotobacter 5 could completely degrade and remove the residues of Atrazine whereas Bacillus polymyxa, B.circulans and Azotobacter 9 partiolly degraded Atrazine comparing to control in different ration.

Regarding to propanocarb, all PGPRs could totally degrade and renoue this pesticide and changing it to save products, whereas pseudomonas floursens reduced the concentration to $0.13 \mathrm{mg} / \mathrm{kg}$ comparied to control. The same trend was observed with chlorpyrifs as B.polymxa, B.subtilis and $B$. circulans reduced the concentration to $0.05,0.02$ and $0.02 \mathrm{mg} / \mathrm{kg}$ respectively. Other PGPRs could completely reduce and remove the residues effect of this pesticide. 
Table 5. Pesticide residues in homogenized agricultural wastewater sample using PGPRs for $48 \mathrm{hr}$ at $30^{\circ}$ C.

\begin{tabular}{|l|c|c|c|c|}
\hline Microbes (PGPR) & Atrazine & Propamocarb & Piperonyl butoxide & Chlorpyrifos \\
\hline Control & 0.1 & 0.14 & 0.0 & 0.05 \\
Bacillus megateriuom & 0.0 & 0.0 & 0.01 & 0.0 \\
Paenibacillus polymyxa & 0.05 & 0.0 & 0.0 & 0.05 \\
Bacillus subtilis & 0.0 & 0.0 & 0.0 & 0.0 \\
Bacillus circulans & 0.03 & 0.0 & 0.0 & 0.02 \\
Pseudomonas fluorocens & 0.0 & 0.13 & 0.0 & 0.0 \\
Azotobacter chroococcum 23 & 0.02 & 0.0 & 0.0 & 0.0 \\
Serratia marcescens & 0.0 & 0.0 & 0.0 & 0.0 \\
Azotobacter chroococcum 9 & 0.0 & 0.0 & 0.0 & 0.0 \\
Azotobacter chroococcum 5 & 0.0 & 0.0 & 0.01 & 0.0 \\
Mix (Azo9,Sr,Bs,Bm,Pf) & 0.0 & 0.0 & 0.0 & 0.0 \\
\hline
\end{tabular}

*Data are expressed as $\mathrm{mg} / \mathrm{Kg}$.

Bacteria were the most enormously available decomposers and were able to degrade the pesticide residues. These pesticide residues can last for long time in the environment depending on the initial concentration of these pesticides and the biodegradation rate (Nawaz et al 2011).

The PGPRs degrade the pesticides as a source of $C, N$ and $P$ (Awed et al 2011). Various researches have reported the pesticides are degraded Co metabolically and that depended on the concentration, solubility and availability of pesticides as essential factors affecting the rate and extent of bioremediation (Eissa et al 2014).

Culture technique was employed in vitro to analyze whether the five bio-agent PGPRs when they used in a mixture form showed inhibition patterns towards both E.coli and Salmonella spp. Through the antagonistic as in Table (6). The mixture of PGPRs exhibited antibacterial potential by inhibiting the growth of both pathogens. The highest inhibition action of (Serratia sp. + Azotobacter chroococcum $9+$ B.megaterium + P.flouresens + B.subtilius) $94.4 \%$ was detected against E.coli and $96.6 \%$ against Salmonella spp. Microscopic study showed that the mixture of PGPRs was able to degrade and utilize the two pathogens cells through production of secondary metabolities and antibiotics that could suppress the pathogens growth and also secreting cell-wall degrading enzymes as mentioned by (Viterbo et al 2002).
The pathogenic bacterial counts: As shown in Figs $(\mathbf{1}, 2)$ Mohate water is polluted by Fecal coliform, Total coliform and salmonella. Finding these pathogenic microorganisms may be due to some people have bad behavior, they throw sludge from trench into running water canal specially in rural environment. The numbers were higher in water after treatment than in soil. The plant growth promoting Rhizobucteria could markedly reduce the numbers of these Pathogenic organisms. This owing to the antagonistic action of these PGPRs specially Azotobacter chrococcoum strains (Azo. 5, Azo. 9 and Azo.23) they all produce cellulase, polygalacturonase and pectin lyase enzymes suppress the action of pathogenic microorganisms through pathogen cell wall lysis and degradations and yet, the death of pathogenic cells this was obivous shown with treatments 8B (T8= Wastewater dilution with water 50:50 microbial treatment with PGPR and using fertilizer (NPK) $50 \%$ ) in irrigation water filterate and in soil respectively. Our findings matched with (Son et al 2014) who found that the selected PGPRs strains could suppress the action of pathogenic bacteria and have inhibitory effects on them (Grobelak et al 2015).

As recorded in Table (7), soluble nitrogen in soil and in the drainage irrigation filtrates vary from one treatment to another where in general a remarkable increase of $\mathrm{NH}_{4}$ in the drainage irrigation filtrate than in soil and the highest ammonium. 
Table 6. Zone inhibition among mixture of five PGPRs strains and some pathogenic bacteria

\begin{tabular}{|l|c|c|c|c|}
\hline \multicolumn{1}{|c|}{ PGPRs } & $\begin{array}{c}\text { Growth } \\
\text { of E.coli } \\
\text { (cm) }\end{array}$ & \% Inhibition & $\begin{array}{c}\text { Growth of } \\
\text { Salmonella } \\
\text { sp(cm) }\end{array}$ & \% Inhibition \\
\hline $\begin{array}{l}\text { Serratia sp. + Azotobacter chroococcum 5 + } \\
\text { Azotobacter chroococcum 9+ Bacillus mega- } \\
\text { terium + Pseudomonas flouracens }\end{array}$ & 2.4 & 73.3 & 2.8 & 68.8 \\
\hline $\begin{array}{l}\text { Serratia sp. + Azotobacter chroococcum 23+ } \\
\text { Bacillus megatheriuom +Pseudomonas } \\
\text { flouracens + Bacillus subtilius }\end{array}$ & 0.5 & 94.4 & 0.3 & 96.6 \\
\hline $\begin{array}{l}\text { Azotobacter chroococcum 3+ Azotobacter } \\
\text { chroococcum 9+ Bacillus megaterium + Pseu- } \\
\text { domonas flouracens + Bacillus polymexa }\end{array}$ & 3 & 66.6 & 3 & 66.7 \\
\hline
\end{tabular}

Inhibition\%= [(D1-D2)/D1] x100. Where: D1=Colony diameter in control, D2=Colony diameter in treatment.

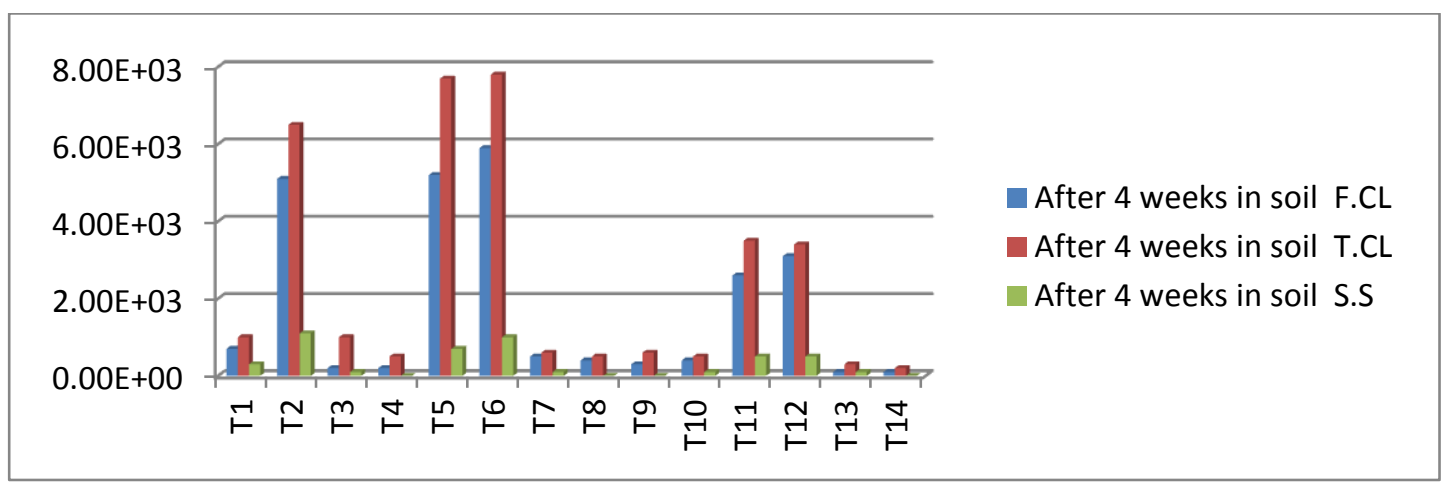

Fig. 1. The Pathogenic bacterial counts (fecal coliform after $48 \mathrm{hr}$ at $44^{\circ} \mathrm{C}$, total coliform and salmonella and shigella after $24 \mathrm{hr}$ at $30^{\circ} \mathrm{C}$. in soil

[Treatments (T1 = Control ( tap water ), T2 = Wastewater (drainage), T3= Wastewater microbial treatment with PGPR and using fertilizer (NPK) 50\%., T4= Wastewater microbial treatment with PGPR and using fertilizer (NPK) 100\%., T5= Wastewater chemical treatment with Nitrification inhibitors fertilizer (NPK) 50\%., T6= Wastewater chemical treatment with Nitrification inhibitors fertilizer (NPK) $100 \%$., T7= Wastewater microbial and chemical treatments using fertilizer (NPK) 50\%., T8= Wastewater microbial and chemical treatments using fertilizer (NPK) 100\%, T9= Wastewater dilution with water 50:50 microbial treatment with PGPR and using fertilizer (NPK) 50\%., T10= Wastewater dilution with water 50:50 microbial treatment with PGPR and using fertilizer (NPK) 100\%., T11= Wastewater diluted with water 50:50 chemical treatment with Nitrification inhibitors fertilizer (NPK) 50\%., T12= Wastewater diluted with water 50:50 chemical treatment with Nitrification inhibitors fertilizer (NPK) 100\%., T13= Wastewater diluted with water 50:50 microbial and chemical treatments using fertilizer (NPK) 50\%., T14= Wastewater diluted with water 50:50 microbial and chemical treatments using fertilizer (NPK) 50\%.]

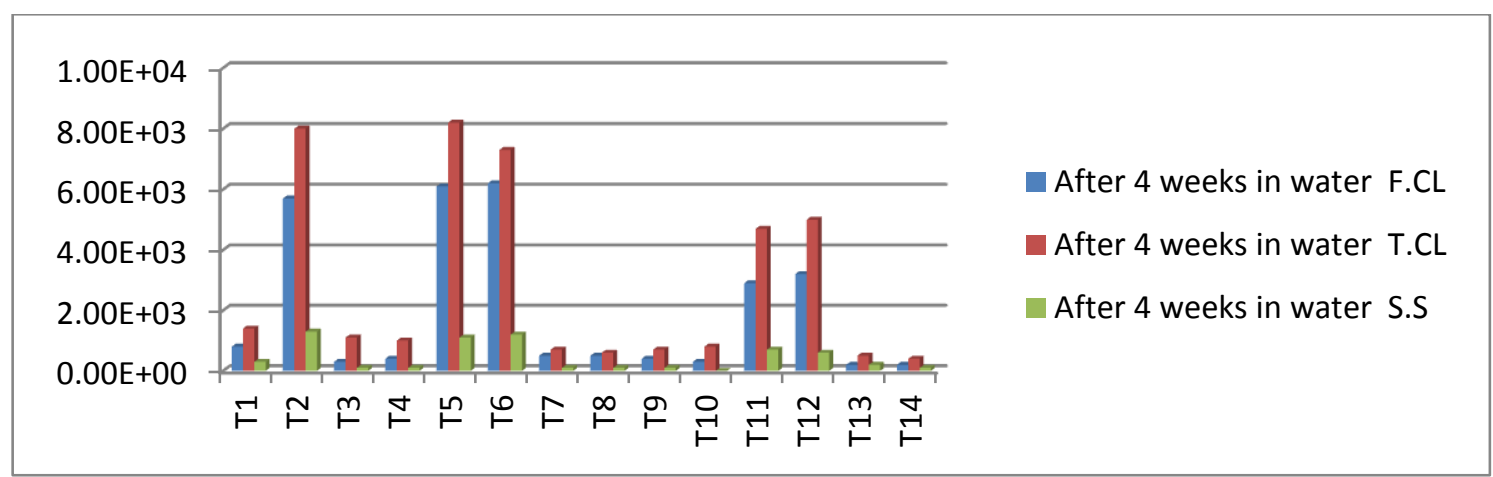

Fig. 2. The Pathogenic bacterial counts (fecal coliform after $48 \mathrm{hr}$ at $44^{\circ} \mathrm{C}$, total coliform and salmonella and shigella $/ \mathrm{ml}$ after $24 \mathrm{hr}$ at $30^{\circ} \mathrm{C}$ 

some horticultural crops

Table 7. Determination of $\mathrm{NH}_{4}, \mathrm{NO}_{2}$ and $\mathrm{NO}_{3}$ in soil and in the drainage irrigation filterate (ppm)

\begin{tabular}{|c|c|c|c|c|c|c|}
\hline \multirow{2}{*}{ Treatments } & \multicolumn{3}{|c|}{ Soluble nitrogen in soil } & \multicolumn{3}{c|}{ Soluble nitrogen in drainage irrigation } \\
& filtrate & \\
\cline { 2 - 7 } & $\mathbf{N H}_{4}$ & $\mathbf{N O}_{2}$ & $\mathbf{N O}_{3}$ & $\mathbf{N H}_{4}$ & $\mathbf{N O}_{2}$ & $\mathbf{N O}_{3}$ \\
\hline T1 & 0.27 & 9.318 & 2.129 & 1.811 & 4 & 39.77 \\
T2 & 0.04 & 3.773 & 2.193 & 2.308 & 4.590 & 46.54 \\
T3 & 1.34 & 41.27 & 1.838 & 8.105 & 31.545 & 16.45 \\
T4 & 2.91 & 24.05 & 0.387 & 8.377 & 32.863 & 20.09 \\
T5 & 0.55 & 21.59 & 0.838 & 1.05 & 33.409 & 55.51 \\
T6 & 0.86 & 43.55 & 0.58 & 1.33 & 34.590 & 62 \\
T7 & 1.48 & 27.59 & 0.516 & 3.7 & 45.181 & 58.12 \\
T8 & 4.16 & 6.955 & 1.45 & 4.6 & 58.863 & 58.41 \\
T9 & 1.1 & 21.23 & 0.451 & 5.6 & 28.363 & 10.35 \\
T10 & 6.51 & 50.59 & 0.516 & 8.6 & 31.863 & 15.09 \\
T11 & 1.81 & 27.95 & 1.225 & 0.87 & 31.954 & 60.03 \\
T12 & 2.11 & 12.59 & 2.22 & 1.21 & 32.954 & 60.45 \\
T13 & 3.7 & 18.68 & 0.87 & 2.39 & 44.681 & 52.32 \\
T14 & 5.7 & 14.05 & 2.70 & 3.22 & 53.863 & 58.03 \\
\hline
\end{tabular}

values were obtained with the treatments T3 8.105, T4 8.377, T9 5.6, T10 6.51 in soil and 8.6 in irrigation filtrate and T14 5.7 in soil and 3.22 ppm in irrigation filtrate.

Treatment T10 and T8 exhibited the optimum $\mathrm{NO}_{2}$ where they recorded 50.59 in soil and 58.86 in irrigation filtrate ppm respectively. In concern, Total nitrogen in soil T14 obtained higher valve 2.7 ppm than all other treatments whereas in the drainage irrigation filtrate Total nitrate T6 treatment recorded $62 \mathrm{ppm}$ more than all other treatments. The increase of $\mathrm{NH}_{4}-\mathrm{N}$ in the drainage filtrate more than it in soil may be due to re-mineralization of nitrogen immobilized at a stage of plant growth (Omar, 1980). The increase of ammonium in irrigated soil was due to ammonification processes.

There are major factors affecting the soluble nitrogen like bacterial inoculation, ammonium sulphate and nitrification inhibitors and these factors led to the increase of $\mathrm{NO}_{2}$ and $\mathrm{NO}_{3}$ in the drainage irrigation water filtrate than in soil. These findings are matched with those obtained by (Nelson and Huber 2001).

Dehydrogenase activity in soil

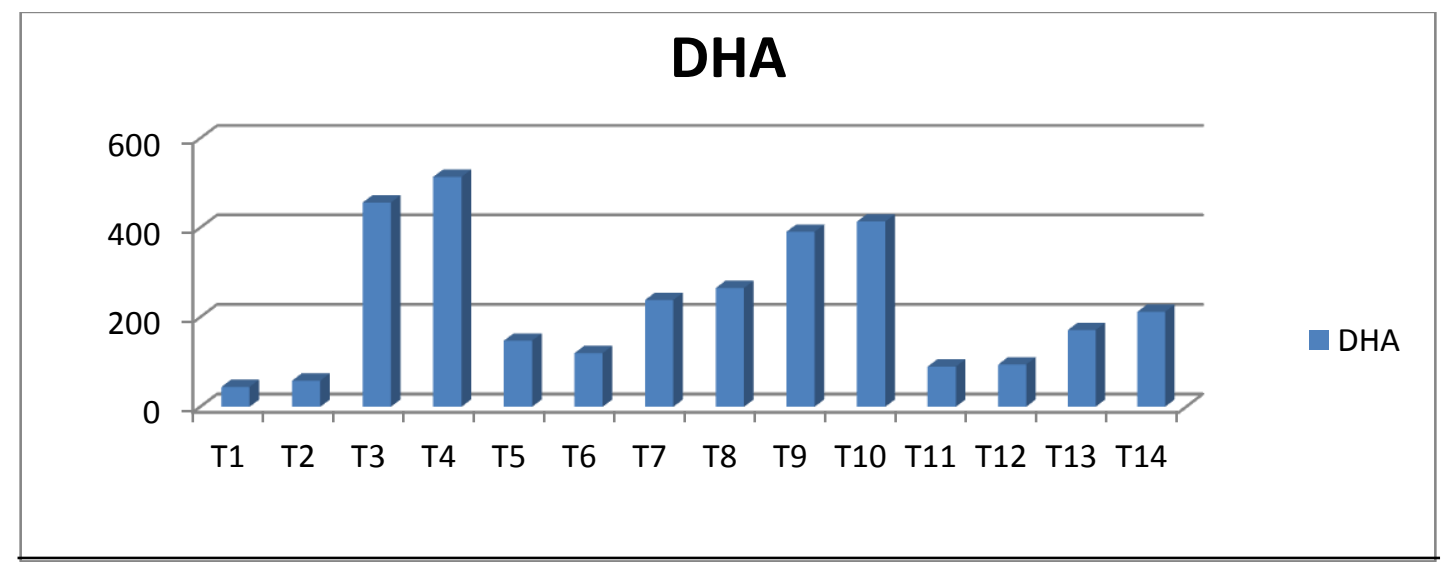

Fig. 3. Dehydrogenase activity in soil ( $\mu \mathrm{g} \mathrm{Tpf} / \mathrm{g}$ dry soil/24 hr). 
It is clear from Fig. (3) that dehydrogenase activity is strongly affected by rhizosphere soil. The dehydrogenase values increased with increasing the populations of viable microbial groups in soil. The activity of this enzyme steadly increase with increasing the root volume of plants, therefore after 4 weeks the activity increased to maximum values specially with treatment $6 \mathrm{~B}$ (Wastewater microbial and chemical treatments using fertilizer (NPK) $50 \%$ ) that recorded $1.52 \mu \mathrm{g} \mathrm{Tpf/g}$ dry soil/day. Dehydrogenase indicates the microbial activity in soil and root surfaces. The increase of dehydrogenase activity as shown in Fig. (5) with 6B (Wastewater microbial and chemical treatments using fertilizer (NPK) 50\%) treatment more than other treatments relied on the viability of PGPRs and other native beneficial microorganisms and the existence in high populations that could colonize the rhizosphere, which led to the increase of $\mathrm{CO} 2$ evolution and carbonic acids formation that decreased soil $\mathrm{PH}$ slightly and enhanced the growth of any plant cultivated in this soil (EL-Gamal et al 2015).

Results in Figures $(4,5)$ show the effect of inoculation with plant growth promoting rhizobacteria on the photosynthetic pigments in both mint and gladiolas plants.
In mint, treatment 6B (Wastewater microbial and chemical treatments using fertilizer (NPK) $50 \%$ ) obtained higher chlorophyll a content 1.030 $\mathrm{mg}$, chlorophyll b $0.796 \mathrm{mg}$ and carotenoids 1.95 $\mathrm{mg}$ than all other treatments besides controls.

In gladiolas, treatment 8A (Wastewater dilution with water 50:50 microbial treatment with PGPR and using fertilizer (NPK) 50\%) was the superior one as it obtained the highest content of chlorophyll a $0.92 \mathrm{mg}$, chlorophyll b $0.811 \mathrm{mg}$ and carotenoids $1.760 \mathrm{mg}$.

PGPRs could enhance plants and improve the growth that reflect on the healthy state of plants were the PGPRs provide plants with the available nutrients such as $\mathrm{N}$ and $\mathrm{P}$ where the two essential elements enter in the stracture of chlorophyll and also, producing phytohormons (biostinulants). IAA (Indole acetic acid), Cytokines and, Gibberellins these compounds has a direct influence an plants as they could increase cell division, cell elongation, increase the surface area of fire roots and yet increasing the availability of nutrients and let the plants in healthy state through the increase of leaves area and number all that positively reflected on improving photosynthes and pigmint content in mint and gladiolas (Grobelak et al 2015).

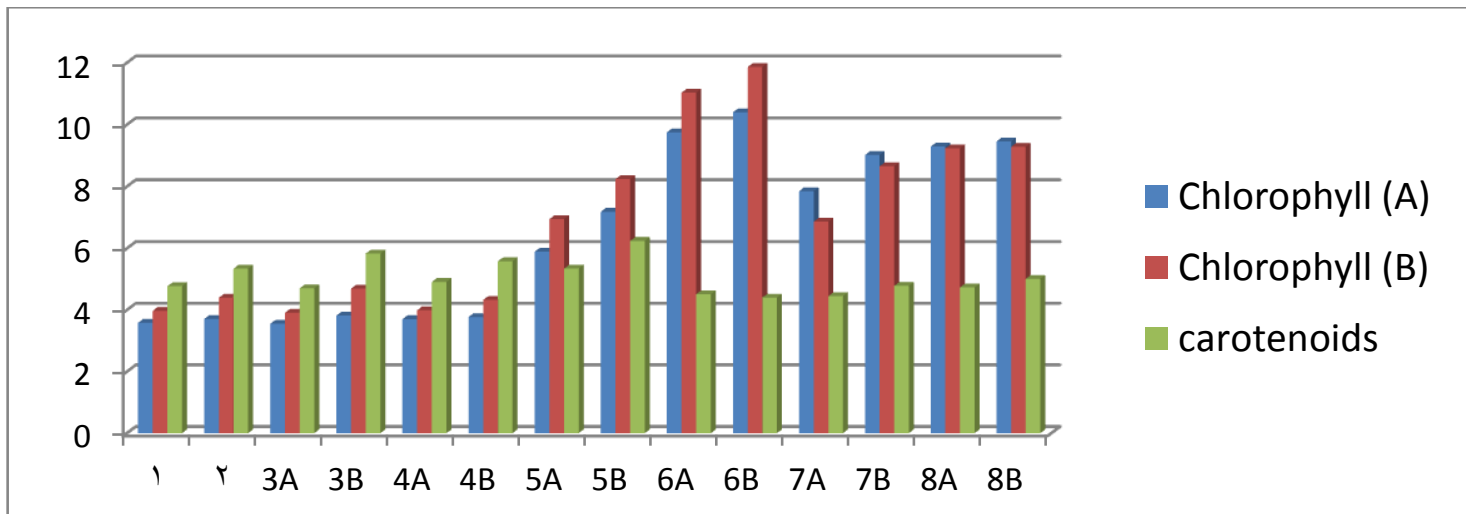

Fig. 4. Determination of Chlorophyll $\mathrm{a}, \mathrm{b}$ and carotenoids ( $\mathrm{mg} / \mathrm{g}$ fresh leaves of Mentha viridis $\mathrm{cv}$ )

Treatments (1 = Control ( tap water ), $\mathbf{2}=$ Wastewater (drainage), $\mathbf{3 A}=$ Wastewater microbial treatment with PGPR and using fertilizer (NPK) 50\%., 3B= Wastewater microbial treatment with PGPR and using fertilizer (NPK) 100\%., 4A= Wastewater chemical treatment with Nitrification inhibitors fertilizer (NPK) 50\%., 4B= Wastewater chemical treatment with Nitrification inhibitors fertilizer (NPK) 100\%., 5A= Wastewater microbial and chemical treatments using fertilizer (NPK) 50\%., 5B= Wastewater microbial and chemical treatments using fertilizer (NPK) 100\%., 6A= Wastewater dilution with water 50:50 microbial treatment with PGPR and using fertilizer (NPK) 50\%., 6B= Wastewater dilution with water 50:50 microbial treatment with PGPR and using fertilizer (NPK) 100\%., 7A= Wastewater diluted with water 50:50 chemical treatment with Nitrification inhibitors fertilizer (NPK) 50\%., 7B= Wastewater diluted with water 50:50 chemical treatment with Nitrification inhibitors fertilizer (NPK) 100\%., 8A= Wastewater diluted with water 50:50 microbial and chemical treatments using fertilizer (NPK) 50\%., 8B= Wastewater diluted with water 50:50 microbial and chemical treatments using fertilizer (NPK) $50 \%$. 


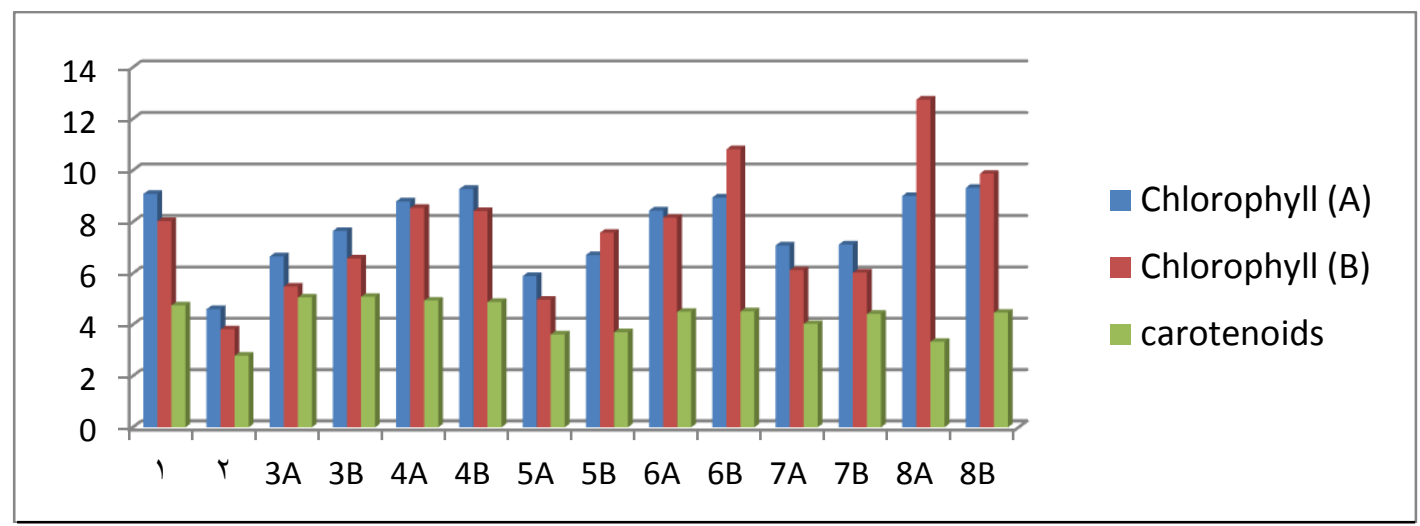

Fig. 5. Chl.a, b and carotenoids ( $\mathrm{mg} / \mathrm{g}$ fresh leaves of Gladiolas)

\section{Morphological prametars}

Table 8. Morphological parameters of Mentha viridis cv plant

\begin{tabular}{|l|c|c|c|c|c|c|}
\hline Treatments & $\begin{array}{c}\text { number of } \\
\text { leaves }\end{array}$ & $\begin{array}{c}\text { plant height } \\
\text { (cm) }\end{array}$ & $\begin{array}{c}\text { stem diameter } \\
\text { (cm) }\end{array}$ & $\begin{array}{c}\text { fresh weight } \\
\text { (g) }\end{array}$ & $\begin{array}{c}\text { Dry weight } \\
\text { (g) }\end{array}$ & $\begin{array}{c}\text { Root length } \\
\text { (cm) }\end{array}$ \\
\hline C & $35.33 c$ & $30.667 a b c d$ & $0.327 b$ & $9.03 a b$ & $2.143 b$ & $42.667 a$ \\
T1 & $52 \mathrm{bc}$ & $16.33 \mathrm{~b}$ & $0.22 \mathrm{~b}$ & $7.73 \mathrm{~b}$ & $1.8 \mathrm{~b}$ & $23 \mathrm{a}$ \\
T2 & $60 \mathrm{bc}$ & $29 \mathrm{bcd}$ & $0.8937 \mathrm{a}$ & $14.27 \mathrm{ab}$ & $3.2 \mathrm{~b}$ & $38.33 \mathrm{a}$ \\
T3 & $42,67 \mathrm{bc}$ & $28.33 \mathrm{~cd}$ & $0.327 \mathrm{~b}$ & $11.47 \mathrm{ab}$ & $2.2 \mathrm{~b}$ & $32.33 \mathrm{a}$ \\
T4 & $54 \mathrm{bc}$ & $29.33 \mathrm{bcd}$ & $0.377 \mathrm{~b}$ & $15 \mathrm{ab}$ & $3.5 \mathrm{~b}$ & $28.667 \mathrm{a}$ \\
T5 & $43.33 \mathrm{bc}$ & $37.66 \mathrm{a}$ & $0.367 \mathrm{~b}$ & $9.83 \mathrm{ab}$ & $2.4 \mathrm{~b}$ & $31 \mathrm{a}$ \\
T6 & $56 \mathrm{bc}$ & $30.3 \mathrm{abcd}$ & $0.367 \mathrm{~b}$ & $13.77 \mathrm{ab}$ & $2.987 \mathrm{~b}$ & $30.3 \mathrm{a}$ \\
T7 & $64 \mathrm{bc}$ & $29.66 \mathrm{abcd}$ & $0.327 \mathrm{~b}$ & $15.47 \mathrm{ab}$ & $3.243 \mathrm{~b}$ & $33.3 \mathrm{a}$ \\
T8 & $156 \mathrm{ab}$ & $36 \mathrm{abc}$ & $0.327 \mathrm{~b}$ & $36.67 \mathrm{a}$ & $7.587 \mathrm{ab}$ & $38 \mathrm{a}$ \\
T9 & $203.33 \mathrm{a}$ & $27 \mathrm{~d}$ & $0.4 \mathrm{~b}$ & $30.57 \mathrm{ab}$ & $12.9 \mathrm{a}$ & $34 \mathrm{a}$ \\
T10 & $34 \mathrm{c}$ & $27.3 \mathrm{~d}$ & $0.293 \mathrm{~b}$ & $8.7 \mathrm{ab}$ & $1.9 \mathrm{~b}$ & $40.3 \mathrm{a}$ \\
T11 & $34.67 \mathrm{c}$ & $36.66 \mathrm{bb}$ & $0.383 \mathrm{~b}$ & $15.8 \mathrm{ab}$ & $3.7 \mathrm{~b}$ & $33.667 \mathrm{a}$ \\
T12 & $162 \mathrm{ab}$ & $29.667 \mathrm{abcd}$ & $0.407 \mathrm{~b}$ & $30.27 \mathrm{ab}$ & $6.267 \mathrm{~b}$ & $33.667 \mathrm{a}$ \\
T13 & $45.67 \mathrm{bc}$ & $23,667 \mathrm{~d}$ & $0.310 \mathrm{~b}$ & $18.37 \mathrm{ab}$ & $3.020 \mathrm{~b}$ & $43 \mathrm{a}$ \\
\hline Duncan & 3782.35 & 18.47619 & 15.6197 & 203.447 & 10.117 & 128.428 \\
\hline
\end{tabular}

Treatments $(\mathbf{C}=$ Control ( tap water $), \mathbf{T 1}=$ Wastewater (drainage), T2= Wastewater microbial treatment with PGPR and using fertilizer (NPK) 50\%., T3= Wastewater microbial treatment with PGPR and using fertilizer (NPK) 100\%., T4= Wastewater chemical treatment with Nitrification inhibitors fertilizer (NPK) 50\%., T5= Wastewater chemical treatment with Nitrification inhibitors fertilizer (NPK) 100\%., T6= Wastewater microbial and chemical treatments using fertilizer (NPK) 50\%., T7= Wastewater microbial and chemical treatments using fertilizer (NPK) 100\%., T8= Wastewater dilution with water 50:50 microbial treatment with PGPR and using fertilizer (NPK) 50\%., T9= Wastewater dilution with water 50:50 microbial treatment with PGPR and using fertilizer (NPK) 100\%., T10= Wastewater diluted with water 50:50 chemical treatment with Nitrification inhibitors fertilizer (NPK) 50\%., T11= Wastewater diluted with water 50:50 chemical treatment with Nitrification inhibitors fertilizer (NPK) 100\%., T12 $=$ Wastewater diluted with water 50:50 microbial and chemical treatments using fertilizer (NPK) 50\%., T13= Wastewater diluted with water 50:50 microbial and chemical treatments using fertilizer (NPK) 50\%. 
Inoculation with plant growth promoting rhizobacteria significantly increased the morphological parameters of mint plants (Table 8) T9 (Wastewater dilution with water 50:50 microbial treatment with PGPR and using fertilizer (NPK) $100 \%$ ) possessed the highest leaves number 203.33 and plant dry weight $12.9 \mathrm{~g}$ respectively.
T5 (Wastewater chemical treatment with Nitrification inhibitors fertilizer (NPK) 100\%) recorded optimum mint height $37.66 \mathrm{~cm}$. highest root length $43 \mathrm{~cm}$ recorded with T13 (Wastewater diluted with water 50:50 microbial and chemical treatments using fertilizer (NPK) 50\%). In concern, the morphological parameters in Gladiolus.

Table 9. Morphological parameters of Gladiolus grandiflorus cv.

\begin{tabular}{|c|c|c|c|c|c|c|c|}
\hline Treatments & $\begin{array}{l}\text { Plant } \\
\text { height } \\
\text { (cm) }\end{array}$ & $\begin{array}{l}\text { Length of } \\
\text { cut spike } \\
\text { (cm) }\end{array}$ & $\begin{array}{l}\text { Diameter of } \\
\text { the first } \\
\text { floret }(\mathrm{cm})\end{array}$ & $\begin{array}{l}\text { Number } \\
\text { of florets }\end{array}$ & $\begin{array}{l}\text { Number } \\
\text { of leaves }\end{array}$ & $\begin{array}{c}\text { Fresh } \\
\text { weight of } \\
\text { cut } \\
\text { spike }(g)\end{array}$ & $\begin{array}{l}\text { Dry weight } \\
\text { of cut } \\
\text { spike(g) }\end{array}$ \\
\hline $\mathrm{C}$ & $95.5^{a}$ & $81^{\mathrm{ab}}$ & $1.57^{\mathrm{a}}$ & $11.5^{\mathrm{bc}}$ & $9.5^{\mathrm{ab}}$ & $74.17^{\mathrm{abc}}$ & $10.25^{\mathrm{abc}}$ \\
\hline $\mathrm{T} 1$ & $69^{b}$ & $56.5^{c}$ & $0.705^{\mathrm{b}}$ & $11.5^{\mathrm{bc}}$ & $8.5^{\mathrm{ab}}$ & $26^{d}$ & $4.85^{c}$ \\
\hline $\mathrm{T} 2$ & $90^{\mathrm{ab}}$ & $76^{\mathrm{ab}}$ & $0.8350^{b}$ & $12.5^{\mathrm{abc}}$ & $9^{a b}$ & $58.4^{\mathrm{abc}}$ & $8.25^{\mathrm{bc}}$ \\
\hline T3 & $94^{\mathrm{a}}$ & $83^{\mathrm{ab}}$ & $0.98^{\mathrm{ab}}$ & $12.5^{\mathrm{abc}}$ & $9.5^{\mathrm{ab}}$ & $70.55^{\mathrm{abc}}$ & $10.25^{\mathrm{abc}}$ \\
\hline T4 & $95^{\mathrm{a}}$ & $82^{\mathrm{ab}}$ & $0.92^{\mathrm{ab}}$ & $10^{c}$ & $10.5^{a}$ & $55.6^{\mathrm{bc}}$ & $9.1^{\mathrm{bc}}$ \\
\hline T5 & $81.5^{\mathrm{ab}}$ & $68.5^{\mathrm{bc}}$ & $0.835^{\mathrm{b}}$ & $11^{\mathrm{c}}$ & $8.5^{\mathrm{ab}}$ & $47.86^{c d}$ & $7.2^{\mathrm{bc}}$ \\
\hline $\mathrm{T} 6$ & $95.5^{\mathrm{a}}$ & $81.5^{\mathrm{ab}}$ & $1.135^{\mathrm{ab}}$ & $11^{\mathrm{c}}$ & $8.5^{\mathrm{ab}}$ & $57.09^{b c}$ & $9.5^{\mathrm{bc}}$ \\
\hline T7 & $96.5^{\mathrm{a}}$ & $81^{\mathrm{ab}}$ & $0.85^{b}$ & $11^{\mathrm{c}}$ & $9.5^{\mathrm{ab}}$ & $59.7^{\mathrm{abc}}$ & $8.95^{b c}$ \\
\hline T8 & $98.667^{a}$ & $80.667^{a b}$ & $0.9267^{a b}$ & $13.33^{\mathrm{abc}}$ & $9^{a b}$ & $63.07^{\mathrm{abc}}$ & $10.067^{\mathrm{abc}}$ \\
\hline T9 & $92.5^{\mathrm{a}}$ & $79.5^{\mathrm{ab}}$ & $0.94^{\mathrm{ab}}$ & $14.5^{\mathrm{ab}}$ & $9.5^{\mathrm{ab}}$ & $71.9^{\mathrm{abc}}$ & $12^{\mathrm{ab}}$ \\
\hline $\mathrm{T} 10$ & $97^{a}$ & $90 a$ & $0.95^{\mathrm{ab}}$ & $12.5^{\mathrm{abc}}$ & $9^{a b}$ & $49.83^{c d}$ & $8.9^{b c}$ \\
\hline $\mathrm{T} 11$ & $92.5^{a}$ & $79^{\mathrm{ab}}$ & $0.83^{b}$ & $11.5^{\mathrm{bc}}$ & $9^{a b}$ & $52.6^{\mathrm{bcd}}$ & $8.65^{\mathrm{bc}}$ \\
\hline $\mathrm{T} 12$ & $101.5^{a}$ & $86.5^{\mathrm{a}}$ & $1.1^{\mathrm{ab}}$ & $15.5^{\mathrm{a}}$ & $7.5^{\mathrm{b}}$ & $86.93^{a}$ & $15.4^{\mathrm{a}}$ \\
\hline T13 & $103^{a}$ & $91^{\mathrm{a}}$ & $0.995^{\mathrm{ab}}$ & $15^{a}$ & $9^{a b}$ & $80.87^{\mathrm{ab}}$ & $12.05^{\mathrm{ab}}$ \\
\hline Duncn & 92.14 & 47.54 & 0.0794 & 2.044 & 1.1 & 146.412 & 5.69 \\
\hline
\end{tabular}

The trend differs from it in mint plants where T3 (Wastewater diluted with water 50:50 microbial and chemical treatments using fertilizer (NPK) 50\%) exhibited better plant height $103 \mathrm{~cm}$ and length of cut spike $91 \mathrm{~cm}$ than all other treatments control treatment recorded the biggest diameter $1.97 \mathrm{~cm}$ of the first floret. T4 (Wastewater chemical treatment with Nitrification inhibitors fertilizer (NPK) $50 \%$ ) obtained the highest leaves namber 10.5 whereas T12 attained the highest floret number 15.5 , fresh wt of cut spike $86.9 \mathrm{mg}$ and dry weight of cut spike $15.4 \mathrm{~cm}$ respectively.

In general addition of bacteria as PGPRs increased plant leaves number, stem biomass, plant height and plant dry weight. PGPRs properties maybe result of synthesis of phytohormons, solubilization of minerals and fungal activities (Grobelak et al 2015).
The percentage of oil content $/ 100 \mathrm{~g}$ mint plant (Table 9 , Fig. 6) was marked higher in both T8 (Wastewater dilution with water 50:50 microbial treatment with PGPR and using fertilizer (NPK) 50\%) and T9 (Wastewater dilution with water 50:50 microbial treatment with PGPR and using fertilizer (NPK) 100\%) where they both obtained the highest percent $1.6 \%$. All other treatments exhibited less percentage.

The role of PGPRs as rhizobacteria is considered very important where these PGPRs could promote plant growth by improving the nutrient status of host plants besides their ability to synthesize and secrete plant hormones like indole-3acetic acid (IAA) Gibberellins (Gas), cytokinins and certain volatiles that altered in increase of oil content in ornamental plants (Perez et al 2014). 


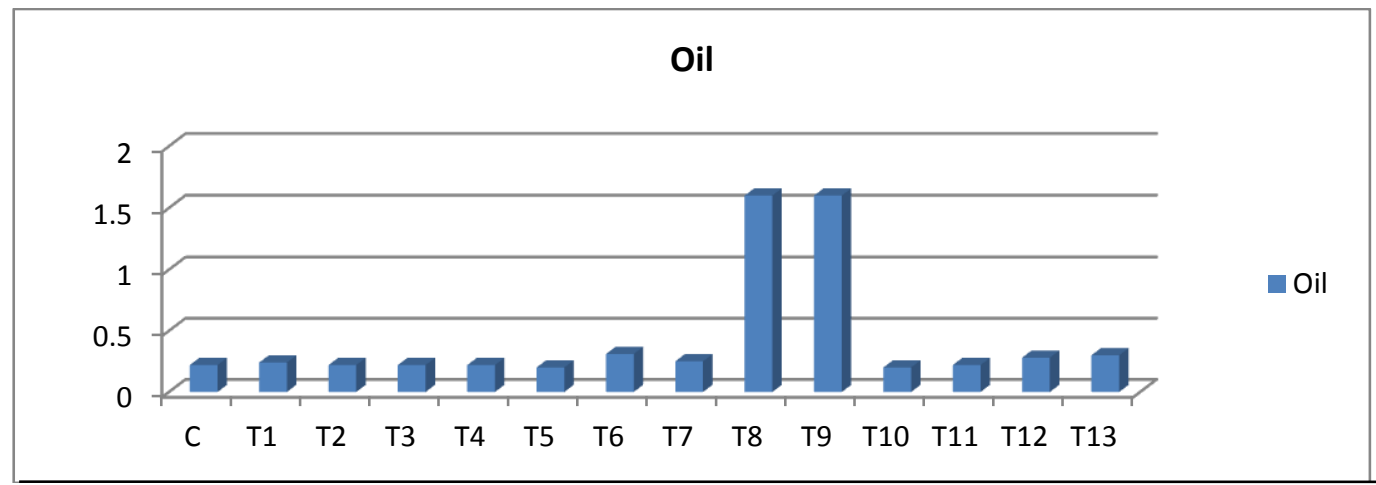

Fig. 6. The titration (\%) in Mint/100g fresh Mentha viridis cv plant

\section{REFERENCES}

Abd El-Malak, Y. and Ishac, Y.Z. 1968 Evaluation methods used in counting Azotobacter. J. Appl. Bact. 331, 269-275.

APHA 1995. Standard Method for Examination of Water and Wastewater. $19^{\text {th }}$ Edition, American Public Health Association, Washington, pp. 2130.

Anonymous 1986, MSTATC. Microcomputer Statistical Programme. Michigan state University, Michigan, Lansing, UAS.

Grobelak, A., Napora, A. and Kacprzak, M. 2015. Using plant growth-promoting rhizobacteria (PGPR)to improve plant growth. Ecological Engineering 84, 22-28.

Awad, N.S., Sabit, H.H., Abo-Aba, S.E.M., Bayoumi, R.A. 2011. Isolation, chlorpyrifosdegrading bacterial strains isolated from Egyptian pesticides-polluted soils. Afr. J. Microbiol. Res., 5, 2855-2862.

British Pharmacopoeia 1963. The Pharmaceutical Press 17 Bloomsbury. Square London, W.C.L.

Cheung, K.C., Poon, B.H.T., Lan, C.Y. and Wong, M.H. 2003. Assessment of Metal and Nutrient Concentration in River Water and Sediment collected from the Cities in the Pearl River Delta, South Chine Chemosohere,52, 1431-1440.

Cochran WG. 1950. Estimation of bacterial densities by means of the most probable number. Biometrics 6, 105-116.

Difco Manual, 1985. Dehydrated Culture Media and Reagents for Microbiology. Laboratories incorporated Detroit. Michigan, 48232 USA. $621 \mathrm{p}$.
Duncan, D.B. 1955. Multiple Range and Multiple F Test. J. Biometrics, 11, 1-42.

Eman, R. Zaki. 2014. Biological treatment of wastewater as a promising technology M.sc, Zagazig University, 1 p.

Eissa, I., Hend, A. Mahmoud, Osama, N. Massoud, Khaled, M. Ghanem and Ibrahim, M. Gomaa 2014. Biodegradation of Chlorpyrifos by Microbial Strains Isolated from Agricultural Wastewater. Journal of American Science 10(3), 3-5.

Feenstra S., Hussain R. and van der Hoek W. 2000. Health Risks of Irrigation with Untreated Urban Wastewater in the Southern Punjab, Pakistan, IWMI Pakistan Report no. 107. International Water Management Institute, and Institute of Public Health, Lahore.

Friedlender, M., Inbar, J. and Chet, I. 1993. Biological control of soilborne plant pathogens by a $\beta-1,3$ glucanase-producing Pseudomonas cepacia. Soil Biol. Biochem., 25(9), 12111221.

Gutiérrez-Mañero, F., Ramos-Solano, B., Probanza, A., Mehouachi, J., Tadeo, F.R. and Talon, M. 2001. The plant-growth-promoting rhizobacteria Bacillus pumilus and Bacillus Iicheniformis produce high amounts of physiologically active gibberellins. Physiol Plant., 111, 206-211.

Heba, M. Hewait, 2010. Biochemical and molecular characterization of some plant growth promoting rhizobacteria (PGPR) groups and its role in developing wheat resistance to rust diseases in saline soil M.Sc., Thesis, Tanta University, Egypt, pp. 18-20.

Karpouzas, D.G. and Singh, B.K. 2006. Microbial degradation of organophosphourus xenobiot- 
ics: Metabolic pathways and molecular basis. Advances in Microbial Physiology, 51, 119185.

Lynch, J.M. 1990. The rhizosphere. Chichester, UK. pp. 111-120.

King, E.O., Ward, M.K. and Raney, D.E. 1954. Two simple media for the demonstration of phycocyanin and fluorescin. J. Lab Clin Med 44, 301-307.

Lee, S.W., Wendy, W., Julius, Y.F.S., Desy, F.S. and Ahmad A.I. 2010. Characterization of antioxidant, antimicrobial, anticancer property and chemical composition of Murdannia bracteata leaf extract. Pharmacol Online, 3, 930-936.

Lee, S.W. and Wendy, W. 2013. Chemical composition and antimicrobial activity of Cymbopogon nardus citronella essential oil against systemic bacteria of aquatic animals. Iran. J. Microbiol., 5(2), 147-152.

Maya, K., Singh, R.S., Upadhyay, S.N. and Dubey, S.K. 2011. Kinetic analysis reveals bacterial efficacy for biodegradation of chlorpyrifos and its hydrolyzing metabolite TCP. Process Biochemistry, 46, 2130-2136.

Manisha, N., Dinesh, S. and Arun, K. 2011. Removal of Heavy Metals from Industrial Effluent Using Bacteria. International J. of Environmental Sci., 2(2), 2.

Manal, A.H. El. Gamal, Hanaa, A. Abokora and Mossoud, O.N. 2015. Impact of formulated Azospirillum lipoferum, Bacillus polymyxa and Nostoc muscorum on wheat productivity. International J. of Chemtech Research 8(9), 100 $-113$.

Nawaz, K., Hussain, K., Choudary, N., Majeed, A., Ilyas, U., Ghani, A., Lin, F., Ali, K., Afghan, S., R, G. and Lashari, M.I. 2011. Ecofriendly role of biodegradation against agricultural pesticides hazards.Afr. J. Microbiol. Res., 5, 177-183.

Nelson, D.W. and Huber, D. 2001. Nitrification inhibitors for corn production. National corn Hand book NCH-56. pp. 240-250.

Omar, M.NA. 1980, Studies on the rhizosohere microflora with Special Reference to nitrogen fixers. M.Sc. Thesis, Ain Shams Univ, Cairo, Egypt. pp. 23-25.

Perez-Montano, F., Allias-Villegas, C., Bellogin, R.A., del Cerro, P., Espuny, M.R., JimenezGuerrero, I., Lopez-Baena, F.G., Ollero, F.G. and Cubo, T. 2014. Plant groth promotion in cereal and leguminous agricultural important plants: From microorganism capacities to crop production. Microbiollogical Research 169, 325-336.

Pikovskaya, R.I., 1948. Mobilization of phosphorus in soil connection with the vital activity of some microbial species. Microbiologiya, 17, 362-370.

S.A.S., 2006. Statistical analysis system, SAS Users Guide: Statisitcs, SAS Institute. Inc. Ediotors, Cary, NC.

Scholz, M. and Xu, J. 2002. Performance comparison of experimental constructed wetlands with different filter media and macrophytes treating industrial wastewater contaminated with lead and copper. Bioresour. Technol. 83, 71-79.

Steel, R.G.D., Torrie, J.H. and Dickey, D. 1997. Principles and Procedure of Statistics.A Biometrical Approach. $3^{\text {rd }}$ Ed., pp. 352-358. Mc Grow Hill Book Co. Inc., New York. USA,

Son, J.S., Sumayo, M., Hwang, Y.J., Kim, B.S., Ghim, S.Y. 2014. Screening of plant growthpromoting rhizobacteria as elicitor of systemic resistance against gray leaf spot disease on pepper. Appl. Soil Ecol 73, 1-8.

Thalmann, A. 1967. Über die mikrobielle aktivität und Ihr Beziehung zu Fruchtbar merkmalen einiger Acherbeden ünter besonderer Berüksichtigung der dehydrogenase aktivität (TTC redakion). Ph.D. Diss., Giesen, W. Germany, pp. 415-425.

Tien, T.M., Diem, H.G., Gaskins, M.H. and Hubbell, D.H. 1979. Plant growth substances produced by Azospirillum brasilense and their effect on the growth of pearl millet (Pennisetum americanum L.). Appl. Environ., 27, 10161024.

Teisseir, H. and Guy, V. 2000. Copper-induced Changes in Antioxdant Enzymes Activities in Frond of Duckweed (Lemna minor). Plant Science, 153, 65-72.

Viterbo, A., Ramot, O., Chernin, L. and Chet, I., 2002. Significance of lytic enzymes from Trichoderma spp. In the biocontrol of fungal plant pathogens. Antonie van Leeuwenhoek 81, 549-556.

Water pollution. 2002. The mcgraw-hill concise encyclopedia of environmental science (9thed). pp. 689-691. New York, N.Y: McGraw-Hill Companies.

Wettestein, D. 1957. Chlorophyll letal under der sul mikovsvopische formmech sell-der plastidein. Exptl. Cell Res., 12, 427-433

Zahra, M.K., 1969. Studies on silicate bacteria. M.Sc. Thesis, Fac. Agric., Cairo University, Egypt pp. 22-23. 